\title{
EDUKASI DENGAN MEDIA LEAFLET DALAM UPAYA PENINGKATAN PENGETAHUAN IBU TENTANG PEMBALUT KAIN
}

\author{
Terry Y.R. Pristya ${ }^{1}$ dan Rizki Amalia ${ }^{2}$ \\ ${ }^{1}$ Program Studi Kesehatan Masyarakat, Universitas Pembangunan Nasional Veteran Jakarta \\ Email: terry.yuliana@gmail.com \\ ${ }^{2}$ Program Studi Kesehatan Masyarakat, Universitas Pembangunan Nasional Veteran Jakarta \\ Email: rizkiamalia@upnvj.ac.id
}

\begin{abstract}
The use of disposable pads has an impact on health and the environment. Health problems that result from using disposable pads include infertility, immune problems, thyroid malfunction, and various types of cancer. Disposable sanitary napkins take 200 to 800 years to decompose in the soil. Besides, if discharged into the river/sea it can endanger the ecosystem and marine animals. The use of cloth pads is still not widely used. The purpose of this community service is to provide education to increase the knowledge of mothers about cloth sanitary napkins using leaflet media. The method used was counseling using colored leaflets. The activity was carried out around the Cipayung TPA to be precise at TPQ Nurul Yaqin on 25 August 2020, with 27 female participants who live in RW 7 , Cipayung Village, Depok. Measurement of participant knowledge using a pretest and posttest with a total of 10 questions. The level of knowledge is categorized into three categories, namely good, sufficient, and insufficient knowledge to know a general description of the level of knowledge. Data analysis using the dependent T-test. The results of the analysis showed that most of the mothers after the counseling had a good level of knowledge (73.1\%). Besides, the average knowledge of mothers also increased from 6.81 to 8.46. Educational activities using leaflet media can significantly increase the knowledge of mothers about cloth sanitary napkins. So that counseling using leaflet media is the right choice.Keywords: Leaflet, knowledge, menspad
\end{abstract}

\begin{abstract}
ABSTRAK
Penggunaan pembalut sekali pakai menimbulkan dampak bagi kesehatan maupun lingkungan. Masalah kesehatan yang diakibatkan dari penggunaan pembalut sekali pakai antara lain: infertil, masalah imun, malfungsi thyroid, serta berbagai jenis kanker. Sampah pembalut sekali pakai memerlukan waktu 200 hingga 800 tahun untuk dapat terurai dalam tanah. Selain itu, jika dibuang ke sungai/laut dapat membahayakan ekosistem dan hewan laut. Penggunaan pembalut kain masih belum banyak digunakan. Tujuan dari pengabdian masyarakat ini adalah memberikan edukasi untuk meningkatkan pengetahuan ibu-ibu tentang pembalut kain menggunakan media leaflet. Metode yang digunakan adalah penyuluhan dengan media leaflet berwarna. Kegiatan dilakukan sekitar TPA Cipayung tepatnya di TPQ Nurul Yaqin pada tanggal 25 Agustus 2020 dengan peserta 27 ibu-ibu yang bertempat tinggal di $R W 7$ Kelurahan Cipayung Depok. Pengukuran pengetahuan peserta menggunakan pretest dan posttest dengan jumlah pertanyaan sebanyak 10 soal. Tingkat pengetahuan dikategorikan menjadi tiga kategori, yaitu pengetahuan baik, cukup, dan kurang untuk mengetahui gambaran secara umum tingkatan pengetahuan. Analisis data menggunakan uji T Dependen. Hasil analisis menunjukkan bahwa sebagian besar ibu-ibu setelah dilakukan penyuluhan memiliki tingkat pengetahuan baik (73,1\%). Selain itu, rata-rata pengetahuan ibu juga mengalami peningkatan dari 6,81 menjadi 8,46. Kegiatan pemberian edukasi menggunakan media leaflet secara signifikan dapat meningkatkan pengetahuan ibu-ibu tentang pembalut kain. Sehingga penyuluhan menggunakan media leaflet menjadi salah satu pilihan yang tepat.
\end{abstract}

Kata Kunci: Leaflet, pengetahuan, pembalut kain

\section{PENDAHULUAN}

Setiap wanita yang sudah pubertas mengalami menstruasi. Menstruasi merupakan endometrium atau dinding rahim seorang wanita yang mengalami peluruhan pada lapisan bagian dalamnya. Menstruasi dialami setiap bulan oleh wanita selama kurang lebih 5 hingga 7 hari. (Kemenkes, 2018). Darah yang keluar dari organ kewanitaan perlu ditampung dengan sebuah wadah yang biasa disebut dengan pembalut (Adrian, 2018).

Selama menstruasi, kebersihan organ intim sangat penting dilakukan. Berbagai jenis pembalut tersedia, diantaranya yang paling populer adalah pembalut sekali pakai atau konvensional. Pembalut jenis ini diproduksi secara massal dengan bahan yang digunakan berasal dari kertas daur ulang melalui berbagai proses kimiawi dengan proses steril dan pemutihan. Kandungan berbahaya 
dalam pembalut sekali pakai terdiri dari klorin, dioxin, aditif petrokimia, dan serat sintesis (Joseph \& Savitri, 2019). Permasalahan dari penggunaan pembalut sekali pakai mencakup masalah kesehatan dan lingkungan. Masalah kesehatan yang diakibatkan dari penggunaan pembalut sekali pakai antara lain: infertil, masalah imun, malfungsi thyroid, serta berbagai jenis kanker (ovarium dan serviks) (WHO, 2016). Sampah pembalut sekali pakai memerlukan waktu 200 hingga 800 tahun untuk dapat terurai dalam tanah. Selain itu, jika dibuang ke sungai/ laut dapat membahayakan ekosistem dan hewan laut (Sasetyaningtyas, 2018).

Selama hidupnya, setiap wanita rata-rata menggunakan lebih dari 16.000 pembalut. Sedangkan di Indonesia sampah akibat dari pembalut sekali pakai mencapai 26 ton (Sasetyaningtyas, 2018). Oleh karena itu, diperlukan alternatif solusi untuk mengatasi permasalah tersebut sebagai pengganti pembalut sekali pakai yaitu dengan zero waste. Cara ini juga biasa disebut menuju nol sampah merupakan upaya dalam rangka mendorong gaya hidup untuk menggunakan kembali produk dengan prinsip refuse, reduce, dan reuse. Sehingga, jumlah sampah yang masuk ke Tempat Pembuangan Akhir (TPA) dapat diminimalisir (Imron, 2019).

Salah satu pengaplikasian zero waste dalam penggunaan pembalut adalah dengan merubah kebiasaan penggunaan pembalut sekali pakai menjadi pembalut kain. Jenis pembalut ini lebih umum dipakai wanita pada puluhan tahun lalu. Bahan yang digunakan hanya terdiri dari potongan kain berbentuk persegi panjang yang diselipkan dalam celana dalam (Joseph \& Savitri, 2019). Namun, seiring berjalannya waktu sekarang sudah banyak yang menggunakan kembali pembalut kain dengan berbagai bentuk yang menarik.

Dari hasil studi pendahuluan yang dilakukan, tidak terkecuali ibu-ibu di sekitar TPA Cipayung Depok juga masih menggunakan pembalut sekali pakai. Kondisi sampah yang semakin menggunung bahkan sampai ditutupi dengan plastik (Nurlitasari, 2020). Sampah tersebut secara tidak disadari merupakan sampah pembalut sekali pakai. Oleh karena itu, diperlukan pemberian edukasi kepada ibu-ibu setempat. Pemberian edukasi kepada masyarakat mengenai pembalut kain diperlukan untuk mulai merubah gaya hidup mereka dalam upaya zero waste. Berbagai media untuk mentransfer informasi kepada sasaran. Salah satunya adalah media leaflet. Media ini terbukti efektif dalam merubah pengetahuan peserta menjadi lebi tinggi dalam kegiatan penyuluhan (Saleh \& Kunoli, 2019). Tujuan dari pengabdian masyarakat ini adalah memberikan edukasi untuk meningkatkan pengetahuan ibu-ibu tentang pembalut kain menggunakan media leaflet.

\section{METODE PELAKSANAAN PKM}

Pengabdian masyarakat yang dilakukan dengan memberikan edukasi menggunakan metode penyuluhan dengan media leaflet. Penyuluhan dilakukan oleh tim untuk mentransfer ilmu tentang pembalut kain kepada masyarakat. Pelaksanaan kegiatan pada tanggal 25 Agustus 2020 di Taman Pendidikan Al-Quran (TPQ) Nurul Yaqin yang berada di wilayah RW 7. Lokasi tersebut merupakan area yang berada paling dekat bahkan berbatasan langsung dengan TPA Cipayung Depok. Peserta penyuluhan sejumlah 27 ibu-ibu warga RW 7 Kelurahan Cipayung Kota Depok. Namun, hanya 26 peserta yang mengisi pretest dan posttest untuk mengetahui tingkat pengetahuan peserta. Jumlah pertanyaan pretest maupun posttest sebanyak 10 buah dengan pertanyaan yang sama. Pertanyaan terdiri dari pengertian pembalut secara umum, pengertian pembalut sekali pakai, pertanyaan pembalut kain, pengertian zero waste, kekurangan pembalut sekali pakai, usaha zero waste, masalah kesehatan yang ditimbulkan, keunggulan pembalut kain, bahaya pembalut kain bagi lingkungan, serta jenis pembalut yang ramah lingkungan.

Data yang didapatkan dari pretest dan posttest dianalisis menggunakan software komputer analisis data. Sebelumnya dilakukan uji normalitas karena data yang didapatkan berupa data numerik untuk 
total skor pengetahuan peserta penyuluhan. Analisis data dilakukan menggunakan uji T dependen untuk mengetahui pengaruh penyuluhan tentang pembalut kain melalui media leaflet terhadap peningkatan pengetahuan peserta. Total skor pengetahuan tersebut kemudian dikategorikan menjadi tiga kategori, yaitu pengetahuan baik, cukup, dan kurang untuk mengetahui gambaran secara umum tingkatan pengetahuan (Arikunto, 2010).

\section{HASIL DAN PEMBAHASAN}

Kegiatan pengabdian masyarakat diawali dengan registrasi peserta yang terdiri dari ibu-ibu yang bertempat tinggal di RW 7 Kelurahan Cipayung Kota Depok. Dari 27 peserta yang tercamtum namanya dalam daftar hadir, hanya sebanyak 26 peserta yang mengisi kuesioner pretest-posttest. Peserta yang tidak mengisi kuesioner dikarenakan hadir terlambat, sehingga tidak mengikuti materi yang disampaikan tim secara penuh dari awal hingga akhir. Pengisian dilakukan sendiri oleh peserta (Gambar 1). Pelaksanaan kegiatan mundur selama 1 jam dari rencana yang sudah dibuat. Hal ini dikarenakan peserta yang hadir masih sibuk dengan aktivitas domestik di rumah masing-masing.

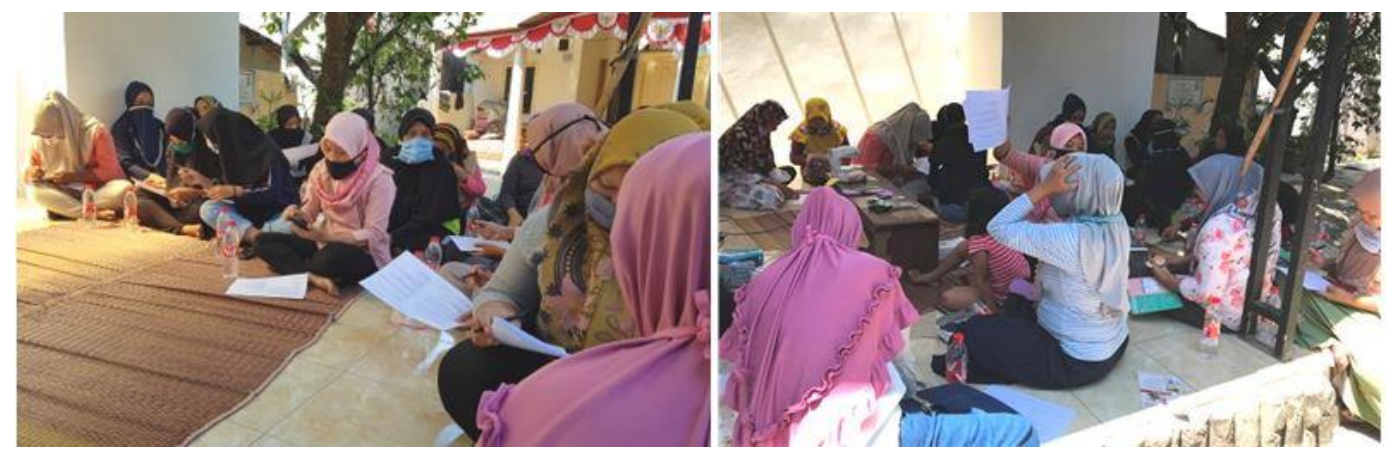

Gambar 1. Pengisian Pretest-Posttest oleh Peserta

Materi penyuluhan yang disampaikan mengenai gambaran sekilas mengenai zero waste (Gambar 2). Karena kegiatan pengabdian dengan tema zero waste di area TPA Cipayung pada tahun-tahun sebelumnya juga telah dilakukan oleh tim. Kegiatan tersebut berupa pembuatan barang kerajinan dengan metode decoupage dari barang-barang bekas, pembuatan ovitrap dari botol bekas untuk menangkap nyamuk, serta pembuatan sabun dari minyak jelantah (Nurcandra, Pristya, \& Fitri, 2018) (Pristya, Fitri, \& Nurcandra, 2020). Materi lainnya yang disampaikan sama dengan yang tertera di leaflet.

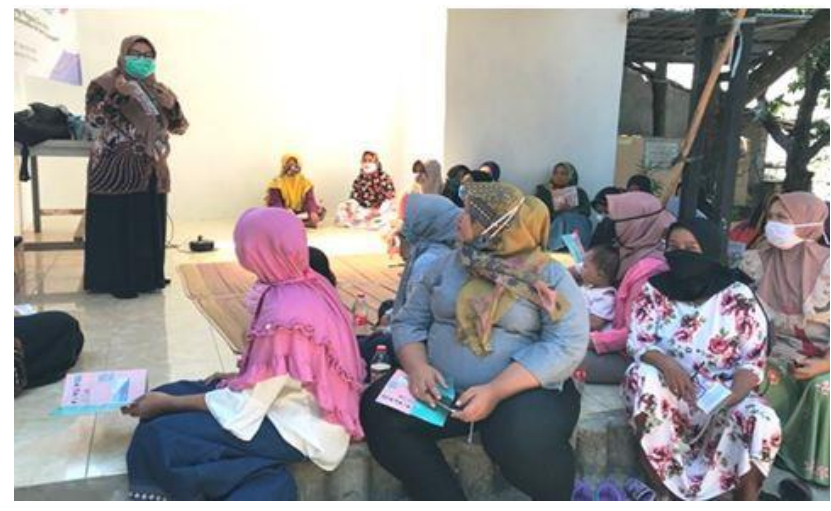

Gambar 2. Pemberian Materi Penyuluhan tentang Pembalut Kain

Leaflet dipilih sebagai media yang digunakan dalam penyuluhan untuk meningkatkan pengetahuan masyarakat tentang pembalut kain. Setiap peserta mendapatkan sebuah leaflet untuk dibawa 
pulang. Judul leaflet yang dibuat tim adalah “Apakah Pembalut Kain Lebih Baik?” (Gambar 3). Desain leaflet dibuat semenarik mungkin dengan warna yang beragam. Beberapa gambar juga ditambahkan untuk memudahkan informasi terserap oleh peserta. dalam leaflet juga dituliskan dengan jelas perbandingan antara pembalut kain dan pembalut sekali pakai atau konvensional.

Informasi yang tertulis pada leaflet meliputi: pengertian pembalut secara umum, pembalut kain dan pembalut sekali pakai; kelebihan dan kekurangan pembalut kain; bahaya pembalut sekali pakai untuk lingkungan dan tubuh; serta perbandingan dari kedua pembalut tersebut dari segi frekuensi pemakaian, bahan pembuatan, efek pada lingkungan dan kesehatan, ketebalan, kelembapan, waktu penggantian, serta harga; dan informasi mengenai zero waste.
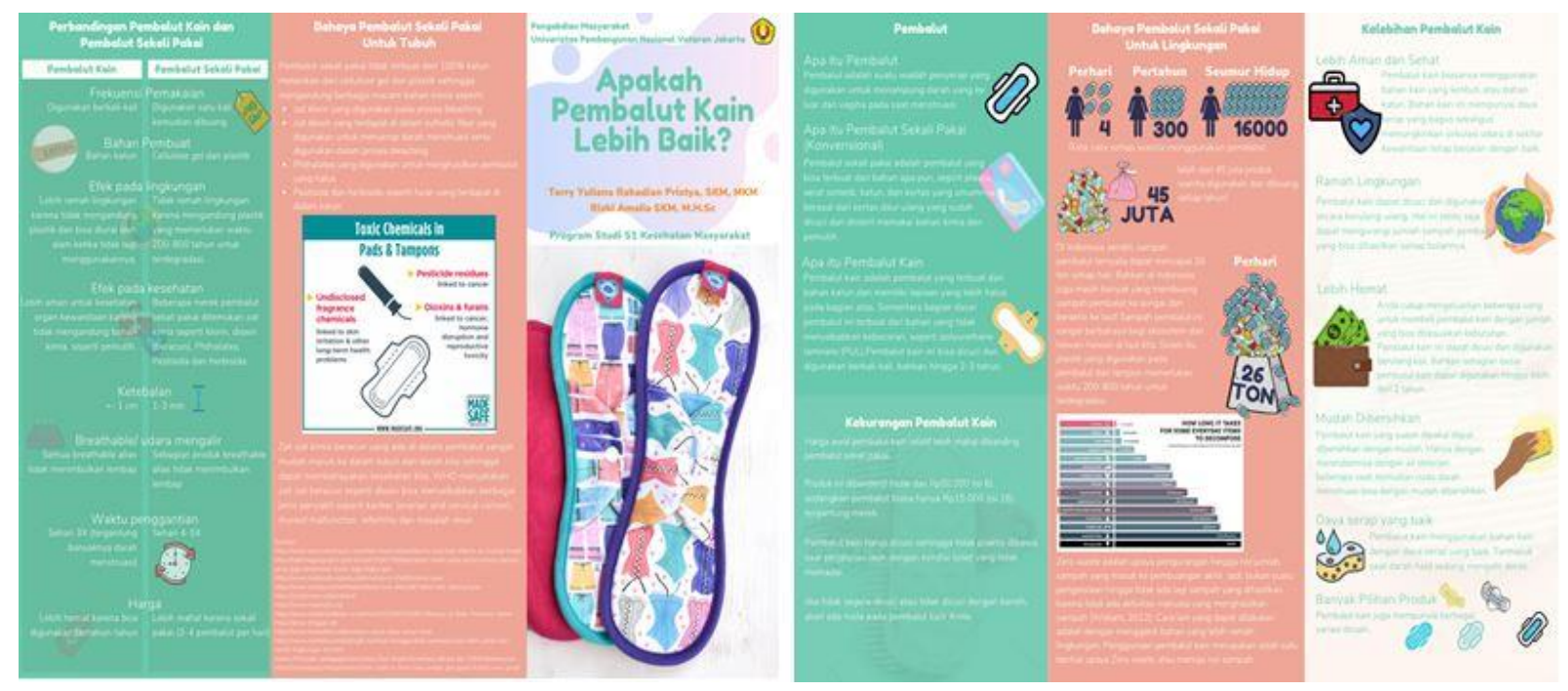

Gambar 3. Media Leaflet "Apakah Pembalut Kain Lebih Baik?”

Leaflet ini dapat dengan mudah dibawa kemana-mana untuk menyebarkan informasi kepada orang lain dibandingkan media lainnya seperti powerpoint. Sehingga, tujuan dari edukasi ini bisa lebih luas, tidak hanya bagi para peserta penyuluhan tetapi bisa meluas ke keluarganya bahkan masyarakat. Tujuan jangka panjang dari penyuluhan yang dilakukan selain meningkatkan pengetahuan masyarakat, juga diharapkan setelah peserta mengetahui bahaya-bahaya yang ditimbulkan akibat pemakaian pembalut sekali pakai untuk dapat merubah kebiasaan ibu-ibu menjadi menggunakan pembalut kain selama menstruasi. Sehingga, pencemaran lingkungan akibat limbah pembalut sekali pakai yang selama ini digunakan tidak bertambah banyak. Kesehatan diri juga menjadi lebih terjaga.

Di akhir sesi setelah materi selesai diberikan, peserta diminta menjawab kembali pertanyaan dalam posttest. Pertanyaan yang diberikan sama pesis dengan saat pretest. Hal ini bertujuan untuk mengetahui besarnya perubahan pengetahuan ibu-ibu setelah diberikan edukasi berupa penyuluhan melalui media leaflet. Dan juga untuk mengetahui apakah media leaflet efektif sebagai media yang dipilih. Pada jawaban yang benar diberi nilai 1, sedangkan jawaban salah diberi skor 0 . Total skor dari 10 pertanyaan tersebut kemudian dikelompokkan menjadi 3 kategori menurut (2010), yaitu: pengetahuan baik, cukup, dan kurang. Pengetahuan baik jika total skor jawaban benar lebih dari 76-100\%, pengetahuan cukup jika total skor jawaban benar $56-75 \%$, dan pengetahuan kurang jika total skor jawaban benar kurang dari 55\%. 
Berdasarkan tabel 1, hasil analisis pengkategorian pengetahuan sebelum penyuluhan terlihat bahwa didominasi dengan pengetahuan baik dan cukup (38,5\%). Sedangkan sesudah penyuluhan, mayoritas ibu-ibu memiliki pengetahuan baik $(73,1 \%)$ tentang pembalut kain. Hal ini menunjukkan bahwa pengetahuan ibu banyak yang meningkat setelah diberikan materi penyuluhan menggunakan media leaflet.

Tabel 1. Distribusi Tingkat Pengetahuan Ibu Sebelum dan Sesudah Penyuluhan

\begin{tabular}{lcccc}
\hline \multirow{2}{*}{ Tingkat Pengetahuan } & \multicolumn{2}{c}{ Pre-test } & \multicolumn{2}{c}{ Post-test } \\
& n & \% & n & \% \\
\hline Baik & 10 & 38,5 & 19 & 73,1 \\
Cukup & 10 & 38,5 & 5 & 19,2 \\
Kurang & 6 & 23,0 & 2 & 7,7 \\
Total & 26 & 100 & 26 & 100 \\
\hline
\end{tabular}

Berdasarkan jenis pertanyaan dalam kuesioner, pada Gambar 4 menunjukkan bahwa pada pertanyaan no. 1 tentang pengertian pembalut dan no.3 tentang pengertia pembalut kain, setelah penyuluhan semua ibu-ibu menjawab dengan benar (100\%). Pada pertanyaan no.5 tentang penyebab bahaya pembalut sekali pakai dan pertanyaan no.8 tentang kelebihan pembalut kain mengalami kenaikan yang cukup signifikan yaitu dari 35\% menjadi $65 \%$ dan dari $38 \%$ menjadi $73 \%$.

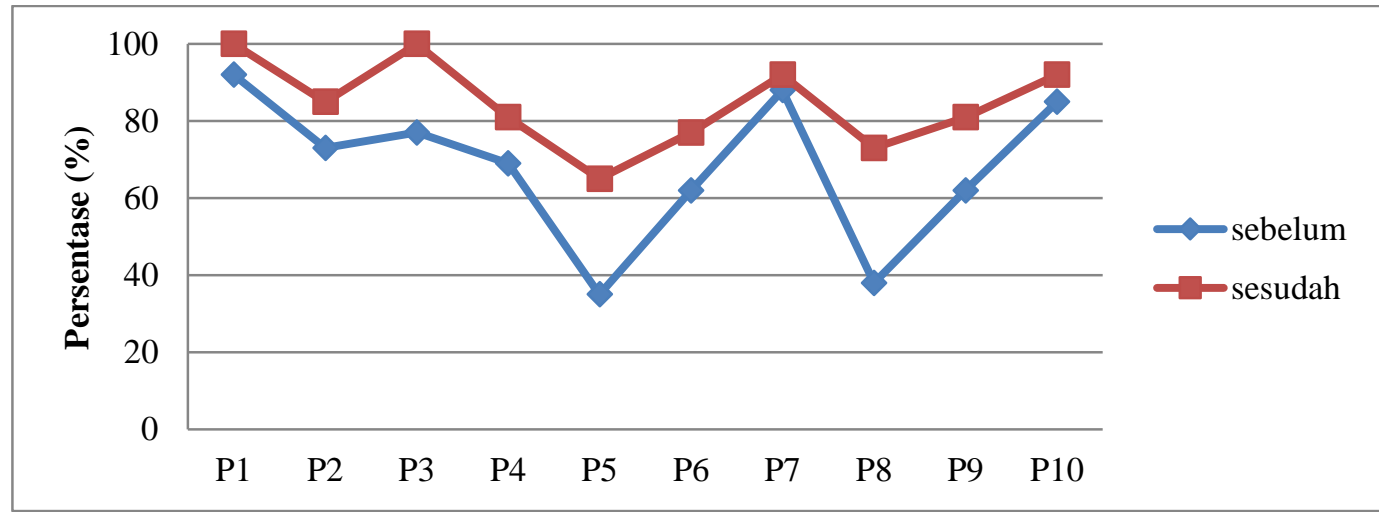

Gambar 4. Persentase Pengetahuan Sebelum dan Sesudah Penyuluhan Menurut Jenis Pertanyaan

Keterangan

P1 : Pertanyaan pengertian pembalut

P2 : Pertanyaan pengertian pembalut sekali pakai

P3 : Pertanyaan pengertian pembalut kain

P4 : Pertanyaan pengertian zero waste

P5 : Pertanyaan penyebab bahaya pembalut sekali pakai

P6 : Pertanyaan pembalut kain dan zero waste

P7 : Pertanyaan bahaya pembalut sekali pakai bagi kesehatan

P8 : Pertanyaan kelebihan pembalut kain

P9 : Pertanyaan bahaya pembalut sekali pakai bagi lingkungan

P10 : Pertanyaan pembalut ramah lingkungan 
Tabel 2 menunjukkan bahwa nilai minimum pretest adalah 1 dan nilai maksimum 10, dengan nilai rata-rata 6,81 . Hal ini menunjukkan bahwa sebelum pelaksanaan penyuluhan, terdapat peserta yang menjawab dengan benar semua pertanyaan dalam kuesioner pretest. Setelah dilakukan penyuluhan, nilai minimum posttest mengalami peningkatan menjadi 4 . Selain itu, rata-rata pengetahuan ibu juga mengalami peningkatan menjadi 8,46. Analisis perbedaan rata-rata pengetahuan ibu sebelum dan sesudah penyuluhan dilakukan menggunakan uji T dependen. Hasil uji statistik menunjukkan bahwa terdapat perbedaan rata-rata yang signifikan pengetahuan ibu sebelum dan sesudah penyuluhan menggunakan media leaflet ( $\mathrm{p}$-value $<0,001$ ).

Tabel 2. Hasil Analisis Perbedaan Rata-Rata Pengetahuan Ibu Sebelum dan Sesudah Penyuluhan dengan Media Leaflet

\begin{tabular}{ccccccc}
\hline Pengetahuan Ibu & Min & Max & Rata-rata & n & SD & P-value \\
\hline Sebelum penyuluhan & 1 & 10 & 6,81 & 26 & 2,21 & $<0,001$ \\
Sesudah penyuluhan & 4 & 10 & 8,46 & 26 & 1,63 & \\
\hline
\end{tabular}

Keterangan: Min $=$ minimun $; \max =$ maksimum $; n=$ jumlah $; \mathrm{SD}=$ standar deviasi

Tabel 2 juga memperlihatkan bahwa media leaflet efektif dalam meningkatkan rata-rata pengetahuan ibu-ibu mengenai pembalut kain sebelum dan sesudah penyuluhan.

\section{KESIMPULAN DAN SARAN}

Kegiatan pemberian edukasi menggunakan media leaflet dapat meningkatkan pengetahuan ibuibu tentang pembalut kain. Sehingga penyuluhan menggunakan media leaflet menjadi salah satu pilihan yang tepat.

\section{Ucapan Terima Kasih (Acknowledgement)}

Terimakasih kepada ibu-ibu warga RW 7 Kelurahan Cipayung khususnya yang berada di sekitar TPA Cipayung atas partisipasinya dalam kegiatan pengabdian masyarakat. Kepada 3 mahasiswa dalam mempersiapkan sarana dan prasarana serta menjadi fasilitator untuk membantu keberhasilan kegiatan. Selain itu, kepada Lembaga Penelitian dan Pengabdian Masyarakat (LPPM) Universitas Pembangunan Nasional Veteran Jakarta atas dukungan moril dan materiil pada pelaksanaan pengabdian kepada masyarakat ini.

\section{REFERENSI}

Adrian, K. (2018). Mencermati Keamanan Pembalut Wanita. Retrieved September 4, 2020, from Alodokter website: https://www.alodokter.com/mencermati-keamanan-pembalut-wanita

Arikunto, S. (2010). Prosedur Penelitian Suatu Pendekatan Praktek. Jakarta: Rineka Cipta.

Imron, M. (2019). What is Zero Waste? Retrieved September 4, 2020, from Zerowaste.id website: https://zerowaste.id/knowledge/what-is-zero-waste-anyway/

Joseph, N., \& Savitri, T. (2019). Pembalut Kain vs Pembalut Sekali Pakai, Mana yang Lebih Sehat? Retrieved September 4, 2020, from helloSehat website: https://hellosehat.com/hidupsehat/perawatan-kewanitaan/pembalut-kain-dan-pembalut-sekali-pakai/\#gref

Kemenkes. (2018). Pentingnya Menjaga Kesehatan Reproduksi Saat Menstruasi. Retrieved January 30, 2020, from Direktorat Promosi Kesehatan dan Pemberdayaan Masyarakat Kementerian Kesehatan website: http://promkes.kemkes.go.id/pentingnya-menjagakesehatan-reproduksi-saat-mentruasi

Nurcandra, F., Pristya, T. Y. R., \& Fitri, A. M. (2018). Pelatihan dan Pembentukan Komunitas Kreatif Sadar Vektor Seitar TPA Cipayung Depok. Kumpulan Abstrak Prosiding Seminar 
Nasional Hasil Pengabdian Kepada Masyarakat. Retrieved from https://conference.upnvj.ac.id/index.php/pkm/article/view/100

Nurlitasari, A. (2020). Tumpukan Sampah di TPA Cipayung Kini Ditutupi Plastik. Retrieved June 28, 2020, from Kompas.com website: https://megapolitan.kompas.com/read/2020/01/29/17162981/tumpukan-sampah-di-tpacipayung-kini-ditutupi-plastik

Pristya, T. Y. R., Fitri, A. M., \& Nurcandra, F. (2020). Kelompok Ibu Cerdas TPA Cipayung: Produksi Sabun Minyak Jelantah sebagai Upaya Zero Waste. Jurnal Pengabdian Pada Masyarakat, 5(1), 205-212. $\quad$ Retrieved from http://ppm.ejournal.id/index.php/pengabdian/article/view/297

Saleh, A., \& Kunoli, F. J. (2019). Pengaruh Penyuuhan dan Pelatihan Melalui Media Leaflet terhadap Pengetahuan Kader PHBS di Kecamatan Ratolindo Kabupaten Tojo Una-Una. PROMOTIF: Jurnal Kesehatan Masyarakat, 8(2), 159-164. https://doi.org/10.31934/promotif.v8i2.498

Sasetyaningtyas, D. (2018). 3 alasan kenapa kita harus stop menggunakan pembalut sekali pakai. Retrieved August 31, 2020, from sustanation.id website: https://sustaination.id/stopmenggunakan-pembalut-sekali-pakai/

WHO. (2016). Dioxins and their effects on human health. Retrieved August 31, 2020, from who.int website: https://www.who.int/en/news-room/fact-sheets/detail/dioxins-and-their-effects-onhuman-health 